\section{Origin of the diphtheroid bacteria, mycoplasmas, etc., reported in association with autoimmune conditions}

SIR, Those of your readers who saw my previous note (Bisset, 1977) on the isolation of a bacterium from the erythrocytes of normal and arthritic subjects may be interested to know how these very slow and lengthy cultural procedures progressed. The final figures gave $30 \%$ positive isolations from 200 persons, who were either healthy or suffering from conditions other than arthritis (Bisset and Bartlett, 1978). Early cultures (which in this case means those only a few weeks old) usually consisted of diphtheroid bacilli or the spheroplasts that are frequently described as mycoplasmas; the latter were often acid-fast or grew as small, acid-fast rods on subculture. All these forms have proved to be phases in the L-cycle of the sporing bacillus now referred to as BLE (Bacillus licheniformis var. endoparasiticus Benedek). Although the rate of reversion to the fully sporogenous, parent form is very low indeed, in primary cultures or subcultures on ordinary medium, further work in this laboratory shows that it can be greatly increased by the use of known L-form reversion stimulants, which serves to substantiate the relationship of the various phases one to another.

These results seem clearly to indicate that most if not all the bacterial forms claimed to be associated with arthritis are forms of a hitherto almost unsuspected cryptoparasite or symbiont of the blood. This includes so-called mycoplasmas, and supporting evidence has recently been provided by Walker and RajBhandary (1978), who have shown by analysis of tRNA sequences, that classical mycoplasmas are related to bacteria of precisely this type. Mutually corroborative evidence from 2 such different sources is much more impressive than either one by itself.

Such a conclusion does not by any means imply that these bacteria are disqualified from playing a role in arthritis or other, mainly autoimmune, conditions. They may act as an immunological irritant, and initiate the sort of interaction, proposed with great clarity of detail by Pease (1965), which seems to be in excellent accordance with the known facts. It is worth keeping a record that Dr Pease was also the first to suggest the true identity of the well-known diptheroid bacilli as they occur in arthritis (Pease, 1974).

K. A. Bisset

Department of Bacteriology, University of Birmingham, Birmingham B15 2TJ

\section{References}

Bisset, K. A. (1977). Isolations of micro-organisms from arthritic patients and healthy normals. Annals of the Rheumatic Diseases, 36, 96.

Bisset, K. A., and Bartlett, R. (1978). The isolation and characters of L-forms and reversions of Bacillus licheniformis var. endoparasiticus (Benedek) associated with the erythrocytes of clinically normal persons. Journal of Medical Microbiology, 11, 335-349.
Pease, P. E. (1974). Identification of bacteria from blood and joint fluids of human subjects as Bacillus licheniformis. Annals of the Rheumatic Diseases, 33, 67.

Pease, P. E. (1965). L-forms, Episomes and Autoimmune Disease. Livingstone: Edinburgh.

Walker, R. T., and RajBhandary, U. L. (1978). The nucleotide sequence of formylymethionine tRNA from $M y c o-$ plasma mycoides ssp. capri. Nucleic Acids Research, 5, 57.

\section{T cells in ankylosing spondylitis}

Sir,

In a recent article in the Annals P. T. Fan et al. (1977) found that the percentage of $T$ cells in peripheral blood of patients with ankylosing spondylitis (AS) was decreased. An increase in null cells was proposed by the authors as an explanation for the lymphocyte abnormality. It is known that a common feature in ankylosing spondylitis is elevated C-reactive protein (CRP).

Morstensten et al. (1975) found that binding of CRP can result in the modulation of certain of the $T$ cell functional characteristics in vitro. According to these authors CRP binds selectively to $T$ lymphocytes and inhibits their ability to form spontaneous rosettes with sheep erythrocytes. By contrast CRP does not bind to B lymphocytes and does not alter such B cell functions as binding to activated complement component or to the Fc portion of immunoglobulin. In view of this the 'decrease' of $T$ cells in peripheral blood of patients with AS may be related to CRP.

DANUTA SoTNIK

Department of Immunology and Rheumatology, Medical School, Poznań, 60-967, Szkolna 8, Poland

\section{References}

Fan, P. T., Clements, P. J., Ju, D. T. J., Opelz, G., and Bluestone, R. (1977). Lymphocyte abnormalities in ankylosing spondylitis. Annals of the Rheumatic Diseases, 36, 471-473.

Mortensen, R. F., Osmand, A. P., and Gewurz, H. (1975). Effects of C-reactive protein on the lymphoid system. I. Binding to thymus-dependent lymphocytes and alteration of their functions. Journal of Experimental Medicine, 141, 821-839.

Sir,

Dr Sotnik's suggestion that the presence of C-reactive protein (CRP) in the peripheral blood of patients with AS may be responisible for our finding of a decreased $\mathrm{T}$ cell percentage in these patients is indeed intriguing and plausible. CRP had been found in 8 of 9 patients with active ankylosing spondylitis ("rheumatoid spondylitis" (Shetlar, et al., 1956) In patients with acute rheumatic fever elevation of CRP is correlated with an increase in the proportions and absolute numbers of CRP-binding lymphocytes(Williams et al., 1978). The CRP binding persisted even after overnight incubation of the lymphocytes in medium at $37^{\circ} \mathrm{C}$ and was found to reside mainly in that population of $\mathrm{T}$ cells bearing receptors for Fc IgG (Williams et al., 1978).

Mortensen et al. (1975) have found that CRP inhibited 
T-cell rosette formation even at a low concentration of $10 \mu \mathrm{g} / \mathrm{ml}$ which is certainly attainable in the serum of inflammatory states where as high as $300 \mu \mathrm{g} / \mathrm{ml}$ of CRP has been reported (Woodland McCarthy, 1951). If indeed increased CRP-binding is present in AS, it would be interesting to isolate this subpopulation since Croft et al. (1976) have shown that CRP binds selectively to antigen-reactive $\mathrm{T}$ cells. This would be one means of identifying the elusive antigen (if it exists) in this HLA B27-related disease.

Peng T. Fan and Rodney Bluestone Wadsworth Hospital Center, Los Angeles, California 90073, USA

\section{References}

Croft, S. M., Mortensen, R. F., and Gewurz, H. (1976) Science, 193, 685.

Mortensen, R. F., Osmand, A. P., and Gewurz, H. (1975)

Journal of Experimental Medicine, 141, 821 .
Shetlar, M. R., Payne, R. W., Padron, J., Felton, F., and Ishmael, W. K. (1956). Journal of Laboratory and Clinica傮 Medicine, 48, 194.

Williams, R. C., jun., Kilpatrick, K. A., Kassaby, M., and Abdin, Z. H. (1978). Journal of Clinical Investigation, 61,, 1384 .

Wood, H. F., and McCarty, M. (1951). Journal of Clinica $\overrightarrow{\text { W }}$ Investigation, 30, 616.

\section{Notes}

\section{Foot congress}

The 13th Congress of the International College of Medicine and Surgery of the Foot will be held at Eastbourne England, on 5-9 June 1979. Inquiries to Miss D. Ambrose, Congress Office, 43 Charles Street, London W1X 7PB. The congress has received recognition in the Advanced Postgraduate Training Scheme.

\section{Editorial Committee of Annals}

Dr Helen Muir and Professor W. Watson Buchanan have resigned from the Editorial Committee of the Annals $\frac{\mathscr{2}}{0}$ In their place have been appointed Dr Michael Denman, clinical immunologist at the Clinical Research Centre, Northwick Park Hospital, Harrow, and Professor D. S. Jackson, professor of medical biochemistry in the University of Manchester. 